Vol..06, No.01, 2020

Doi: https://doi.org/10.24198/cosmogov.v6i1.23944

http://jurnal.unpad.ac.id/cosmogov/index

\title{
E-GOVERNMENT EFFECTIVENESS IN COMBATING CORRUPTION AND IMPROVING PUBLIC SERVICES
}

\author{
Wendra Afriana ${ }^{1}$ \\ Harmawan Susetiyana ${ }^{2}$ \\ Oktarina Maharani ${ }^{2}$ \\ Harry Azhar Azis ${ }^{1}$ \\ ${ }^{1}$ Badan Pemeriksa Keuangan (BPK) RI \\ Jl. Jenderal Gatot Subroto No. 31, DKI Jakarta, Indonesia \\ ${ }^{2}$ Pemerintah Provinsi DKI Jakarta \\ Jl. Medan Merdeka Selatan 8-9 Blok B Lt 3, DKI Jakarta, Indonesia \\ Correspondence Email: weiyacb@gmail.com
}

Submitted: October16, 2019, Reviewed: April 03, 2020, Accepted: April 23, 30

\begin{abstract}
The government's step to be able to fight corruption is not just a discourse. One effort that has been made is e-government. E-government is a model of government system that utilizes information technology in providing information and services for its citizens. The aim is to create good governance that is free from corruption so that it has an impact on better quality public services. Some research shows e-government can reduce corruption and improve public service delivery through transparency and accountability by considering the type of corruption. This research uses qualitative methods and descriptive. Data collection techniques used are literature, such as books, articles and research results relating to e-government in Indonesia and other countries in combating corruption. The results showed, first, the successful implementation of e-government to reduce corruption was highly dependent on the state of the country's political economy. While in an economic perspective, the success of e-government depends on the country's information and communication technology (ICT) infrastructure, one of which is the level of internet penetration. Second, e-government is considered not always effective in reducing various types of corruption. for minor corruption, the application of e-government is considered effective. Meanwhile, for major corruption, such as irregularities in the use of budget and mega corruption involving politicians, it is more difficult to deal with just implementing e-government.
\end{abstract}

Keywords: e-government, corruption, public services

\begin{abstract}
ABSTRAK
Langkah pemerintah untuk bisa memerangi korupsi bukan hanya sekadar wacana. Salah satu upaya yang sudah dilakukan adalah e-government. E-government merupakan model system pemerintahan yang memanfaatkan teknologi informasi dalam memberikan informasi dan pelayanan bagi warganya. Tujuannya untuk mewujudkan tata kelola pemerintahan yang baik dan bersih dari korupsi, sehingga berdampak pada kualitas pelayanan publik yang lebih baik. Beberapa penelitian menunjukkan e-government dapat mengurangi korupsi dan memperbaiki penyampaian layanan publik melalui transparansi dan akuntabilitas dengan mempertimbangkan jenis korupsi. Penelitian ini menggunakan metode kualitatif dan lebih bersifat deskriptif. Teknik pengumpulan data yang digunakan adalah dengan penelusaran studi kepustakaan, baik itu buku, artikel dan hasil penelitian yang berkaitan dengan e-government di Indonesia dan negara lain dalam memberantas korupsi. Hasil penelitian menunjukkan, pertama, keberhasilan implementasi e-government untuk mengurangi korupsi sangat bergantung pada kondisi ekonomi politik negara. Sementara dalam sudut pandang ekonomi, keberhasilan e-government bergantung pada infrastruktur teknologi informasi dan komunikasi (TIK) negara yang salah satu indikatornya adalah tingkat penetrasi internet. Kedua, egovernment dianggap tidak selalu efektif untuk mengurangi berbagai jenis korupsi. untuk korupsi kecil, penerapan e-government dianggap efektif diterapkan. Sementara untuk korupsi besar seperti
\end{abstract}


Vol..06, No..01, 2020

Doi: https://doi.org/10.24198/cosmogov.v6i1.23944

http://jurnal.unpad.ac.id/cosmogov/index

penyimpangan penggunaan anggaran dan mega korupsi yang melibatkan politisi lebih sulit ditangani hanya dengan menerapkan e-government.

Keywords: e-government, korupsi, pelayanan publik

\section{BACKGROUND}

The main task of the government is to provide the best public services for its citizens; it is not enough just to be of standard quality. To realize this, the government must certainly be able to overcome obstacles that can weaken the quality of public services, one of the contributing factors is corruption.

The relationship between corruption and poor public services is linear. For example, in the process of procuring infrastructure projects. The choice of a contractor based on bribery has a high likelihood that the contractor who wins through this method is not motivated, does not comply with the rules and consequently low service quality. (RoseAckerman in Berkovich, 2015).

This is also reinforced by the results of Berkovich's research (2016) which suggests that one major problem that damages the quality of public services to citizens is corruption. Besides corruption, other factors are time, cost and excessive bureaucratic procedures (Singh et al., 2010). However, among these other factors corruption is the most pervasive and least confronted (Davis, 2004).

Meanwhile, based on the principalagent-client model, it is found that a corrupt relationship can reduce public services. Several authors have considered the impact of corruption on public services (for example, Olken, 2007; Reinnika \& Svensson, 2005; Bertrand et al 2007).

Olken (2007) shows that corruption in road construction projects will greatly affect the quality of road infrastructure. Reinnika \& Svensson (2005) revealed that corruption by local bureaucrats can affect reducing enrollment and student performance in Uganda. Besides, Bertrand et al. (2007) examined that bribery in the service process of a Driving License (SIM) in India caused a driver who could not drive to have a SIM.

Lack of budget transparency causes officials to have 'play' space with the budget without being controlled by other parties. Reinikka and Svensson (2005) explain how the dissemination of government project information to the public can reduce corruption, namely by budget transparency. The results of his research show that with transparency in the government budget, it can reduce illegal budget cuts from local bureaucrats on education grant programs in Uganda. When the information is made public in newspapers, corruption in educational grants is reduced. This means that with information transparency, corruption can be prevented.

While in Indonesia, corruption is mostly done in the infrastructure sector. Indonesia Corruption Watch (ICW) data shows 63 out of 211 cases that are being handled by the Police, Attorney General's 
Vol..06, No.01, 2020

Doi: https://doi.org/10.24198/cosmogov.v6i1.23944

http://jurnal.unpad.ac.id/cosmogov/index

Office and the Corruption Eradication Commission in the first semester of 2016, are cases of infrastructure corruption. One of the cases was the DWP who was convicted and found guilty of accepting bribes on the Tehoru-Laimu road widening project, Maluku (Tirto, 2017). No different, the results of FITRA's research also show that the infrastructure sector is the sector that is the most corrupted. The modes include mark up, markdown, fictitious reports, abuse of authority and embezzlement. (Fitra, 2019).

This condition is an indication that supervision is needed for the modes that are often used in corruption, namely technological innovation so that the public knows the details of the implementation budget and program accountability reports.

Along with technological advancements, the government is demanded to be more innovative in providing public services, both in terms of convenience and speed. These efforts are implemented in the form of e-government. E-government is an application that was built to facilitate and accelerate public services through internet technology. In principle, e-government is built to improve the quality of public services through an online system, so that government work can be controlled by the public. The forms of e-government include e-budgeting, eprocurement, e-audit, e-catalog, e-payment, and e-controlling.

However, nine years since Presidential Instruction No. 3/2003 on National Policies and Strategies for eGovernment Development was signed, $55 \%$ of e-government developments in Indonesia are still in the emerging stage,
$28 \%$ enhanced stage, $17 \%$ interactive stage and only one local government reached the transaction stage Nurdin (2012). These conditions also contributed to Indonesia's EGDI (E-Government Development Index) ranking.

In 2018, Indonesia's EGDI ranking is 107. This means it has risen 9 ranks compared to 2016 which only ranked 116. However, Indonesia's ranking is still far below that of ASEAN countries. Singapore was ranked 7th, Malaysia (48), Brunei Darussalam (59), Thailand (73), Philippines (75), and Vietnam (88). This is certainly a whip for the government to be able to improve the implementation of egovernment throughout the country. Considering the growth of Indonesian internet users is always increasing.

Data from the Association of Indonesian Internet Service Providers (APJII) found that 143.26 million Indonesians were using the internet in 2017. Up almost 10 million from 2016 which only amounted to 132.7 million residents (Sakina in Kompas, 2018). For this reason, the government must be innovative in using internet technology to increase the level of public service satisfaction which will, in turn, affect the acquisition of the corruption perception index (GPA).

A country with a low level of corruption will have a good quality of public services. because public services are very vulnerable to various irregularities including corruption. According to world bank data (2018), Indonesia's Government Effectiveness Index (IGE) is 0.18 and GPA 38, compared with Singapore which has a suspension of 2.23 (IGE) and 85 for GPA, 
Vol..06, No.01, 2020

Doi: https://doi.org/10.24198/cosmogov.v6i1.23944

http://jurnal.unpad.ac.id/cosmogov/index

as well as Malaysia with IGE suspension of 01.08 and GPA 53. It means good public services, linear with a decrease in corruption. The lower the level of corruption, the better the quality of public services.

Promoting transparency and accountability may be the two most effective e-government functions in reducing corruption. The easiest way to implement e-government is to implement web-based technology which is a core and inseparable part of every e-government government (Wong \& Welch, 2000). The concept of e-government develops because it is linear with the development of the globalization era that demands innovation in technological and information advancements to encourage improvement in the quality of life of the people.

With the implementation of egovernment in the form of a website will facilitate service to the community. As a result, the level of public dissatisfaction with the government will decrease with the implementation of e-government. Besides, the community has the potential to be able to know and access the course of government. This as a simple benchmark has been implemented the principles of good governance in government, namely transparency and accountability.

Transparency in this context is that the government uses website media and web-based technology to convey information about budgets, activities, and projects that have been or will be carried out. Transparency can also empower citizens to have more access to monitor government activities. Besides, the provision of interactive technology can also improve government accountability because it makes the government more responsive to the demands of citizens (Wong \& Welch, 2000).

In this way, a clear relationship can be found between e-government and improving public services and reducing corruption. Several other studies have shown that e-government has been proven to reduce corruption and improve public service delivery. Shim and Eom's research (2008) shows that e-government is an effective tool to reduce corruption by promoting good governance.

While Cho and Choi (2004) use the OPEN system for the public to accessing permits, registrations, procurement, contracts, and approvals submitted online by the community. This system is a form of e-government innovation that is considered capable of controlling corruption because the administrative process occurs transparently for anyone, anytime and anywhere to submit applications and monitor the review process and approval online until the final decision. This finding is corroborated by Kim, S., Kim., H., J., and Lee (2009) who stated that the OPEN system is an anticorruption system that has a positive impact on reducing corruption, with the leading factor being the main key to its success.

Following in the footsteps of previous research, this study wants to examine the linkages of e-government effectiveness in reducing corruption and improving public services, with the main emphasis on the condition of using the internet to access the field of public services by only $0.4 \%$. The percentage of internet users experiencing high growth in 
Vol..06, No.01, 2020

Doi: https://doi.org/10.24198/cosmogov.v6i1.23944

http://jurnal.unpad.ac.id/cosmogov/index

Indonesia, in fact,most of them access the internet to fulfill their lifestyle rather than to access public services. Based on these data, new questions arise, namely the effectiveness of e-government in combating corruption and improving the quality of public services in Indonesia if the percentage of utilization of public service access is only $0.4 \%$.

\section{METHOD}

The focus of this study is to reveal the conditions and developments of egovernment in Indonesia with the percentage of internet user in accessing the field of public services only $0.4 \%$ (APJII, 2018). With the growth of internet users, the government must be able to take advantage of opportunities to improve public services based on technological innovation, so that the implementation of egovernment can be utilized as much as possible to provide public information disclosure in the absorption of the budget.

To answer the focus of the problem, this study uses a type of qualitative research, because researchers will put more emphasis on observing the development of the use of the internet by the public. Is it more for accessing public services (e-government forms) or for other purposes, such as fulfilling lifestyles?

This is based on the idea that egovernment as an electronic-based governance system is certainly very dependent on the internet. That is, with the growth of internet users, it should have a strong impact on improving public quality and narrowing corruption. This can be realized if the use of the internet is used to access public services rather than merely fulfilling a lifestyle.

To strengthen this assumption, the data collection technique used is a literature study in the form of books, journals, newspapers, and internet that reviews the development of e-government conditions, both in Indonesia and other countries and the development of corruption that occurs in Indonesia, so that a comprehensive recommendation will be obtained and broad to improve the implementation of egovernment by the main objectives of its formation namely improving public services and carrying out an effective, efficient, transparent and accountable government.

\section{RESULT AND DISCUSSION}

Conditions of Public Services in Indonesia

Indonesia has implemented decentralization which has an impact on regional government autonomy to provide public services to citizens. One of the goals of decentralization is to make the government more responsive to the needs of citizens, especially those related to public services such as education, health, infrastructure, and utilities. However, after being decentralized for more than 15 years, the conditions of providing public services in Indonesia have not been as good as the goals set.

Quoting the Ombudsman data (27 November 2019), the level of government compliance in meeting public service standards is still not optimal. From a total survey of 17,717 services and 2,366 service units conducted at 4 Ministries, 3 Institutions, 6 Provinces, 36 City 
Vol..06, No.01, 2020

Doi: https://doi.org/10.24198/cosmogov.v6i1.23944

http://jurnal.unpad.ac.id/cosmogov/index

Governments and 215 District

Governments. An assessment of the ministry shows that $50 \%$ belong to the green zone (predicate of high compliance) and $50 \%$ to yellow zone (predicate of moderate compliance). Meanwhile, institutions show that they are all in the yellow zone with 1,186 service products.

Furthermore, an assessment of the provincial government showed $33.33 \%$ of the provincial government included in the green zone. $50 \%$ yellow zone and $16.67 \%$ red zone (predicate low compliance). The most commonly violated component of public service standards is the right of people to obtain fast and transparent information about the flow and mechanism of licensing and non-licensing that users of access services do not fulfill the obligation to publish system indicators, mechanism,s and procedures.

As for the assessment of the district government, $26.51 \%$ of the district government entered the red zone, $40.47 \%$ the yellow zone and $33.02 \%$ green zone with 15,629 service products spread across 215 district governments. The components of public service standards most frequently violated are those related to the rights of disability groups to have easy and appropriate access and facilities as well as the right of service users to assess service providers through customer satisfaction measurement tools.

The low compliance has an impact on the number of public reports in 2019 reaching 11,087 complaints. Up 102 compared to 2018 which reached 10,985 complaints. Local Government is the most reported party complained by the public relating to public services $(41.03 \%)$. The second rank is occupied by the police agency (13.84\%), the next position is government agencies and ministries with 9.87\%. (Ombudsman, 2019).

With the above conditions, it can be analyzed that public service standards are still ignored by the government. This is indicated by the high percentage of government in the red zone. If the standard of public service is still ignored, it will certainly have an impact on deteriorating service quality. With poor service quality, the consequence of the acquisition of Indonesia's competitiveness value remains low, and Indonesia's GPA will continue to stagnate in the range 37-38 which means it is still classified as a corrupt country. This condition is in line with the results of Lewis's (2017) study that investigated the impact of Indonesian regional government spending on education, health, and infrastructure.

His study revealed that local government spending in Indonesia is positively correlated with increased access to public services in education, health, and infrastructure. However, he also found that this correlation only reached a certain point where after this point the relationship became negative. This point is said at the 75th percentile of total local government spending. Lewis (2017) claims that corruption is one of the reasons why the correlation is not positive across the expenditure range. Thus, it can be said that the state has not yet succeeded in providing quality public services so that the gaps in corruption are still found. 
Vol..06, No.01, 2020

Doi: https://doi.org/10.24198/cosmogov.v6i1.23944

http://jurnal.unpad.ac.id/cosmogov/index

\section{Corruption in Indonesia}

The Corruption that has become deeply entrenched into the culture in Indonesia turned out to be well known during the Dutch colonialism. Ongkhokham in Mochtar Lubis and James C. Scot (1985) said that corruption was known since the modern system of government, namely when Dutch colonialism began to separate personal and public interests. In this system, known officials are people who are given power or authority, and the abuse of these constitutes a betrayal of public trust. And corruption is a term used. Corruption in this context is in the form of abuse of power in using state money to be used for personal or group interests, so that state money that is supposed to be used for the welfare of the people does not have an impact or is linear with the improvement of public interest services.

This was also reinforced by Lewis, that one of the causes of government spending does not always have a positive relationship with increasing public interest is due to corruption. This is corroborated by
Kompas Research and Development data (December 2019) which shows that approximately $57.6 \%$ of cases of corruption of regional heads are directly related to public rights. Such as roads, bridges and schools and includes a health budget. While analyzing, decentralization increases the opportunities for corruption carried out by the Regional Head. This is also corroborated by Rinaldi's research which shows that the practice of Law 22 of 1999 concerning decentralization opens huge opportunities for corruption (Rinaldi in Kurniawan, Prasojo \& Gunadi, 2017).

It is said that local government in Indonesia is weak, so that any benefits from the budget spent and public services that are expected to be received by the majority of citizens as a function of the decentralization of taxes to the regions, cannot be fulfilled because of corrupt practices by the local elite. (Bardhan \& Mookherjee in Lewis, 2017). Besides, the poor performance of local governments is often caused by corrupt budget practices, especially related to tendering public works projects

(Lewis,

2017).

Table 1 Regional Head Corruption Based on Case Type

\begin{tabular}{ccc}
\hline No & Type of Case & Amount \\
\hline 1 & Bribery Infrastructure & 31 \\
2 & APBD Misuse & 20 \\
3 & Other Bribery & 18 \\
4 & Bribery of Natural Resource & 16 \\
& Licensing & \\
5 & Bribe on APBD Discussion & 10 \\
6 & Bribery of the Judiciary & 10 \\
7 & Misuse of infrastructure funds & 9 \\
8 & Other Corruption & 6 \\
9 & Bribery Procurement Position & 5 \\
10 & Money Laundering Crime & 4
\end{tabular}

Source: Compass R\&D analysis of 139 corruption cases involving 121 regional heads (Desember, 2019) 
Vol..06, No.01, 2020

Doi: https://doi.org/10.24198/cosmogov.v6i1.23944

http://jurnal.unpad.ac.id/cosmogov/index

Table 1 clearly shows that corruption involving regional heads is still related to the livelihoods of many people namely in public services. not only that, almost the spread of regional heads entangled in corruption, is evenly distributed in each province. The largest percentage is in West Java Province (11.6\%), followed by East Java and North Sumatra (10.7\%).

Table 2 Percentage of Regional Head entangled in Corruption

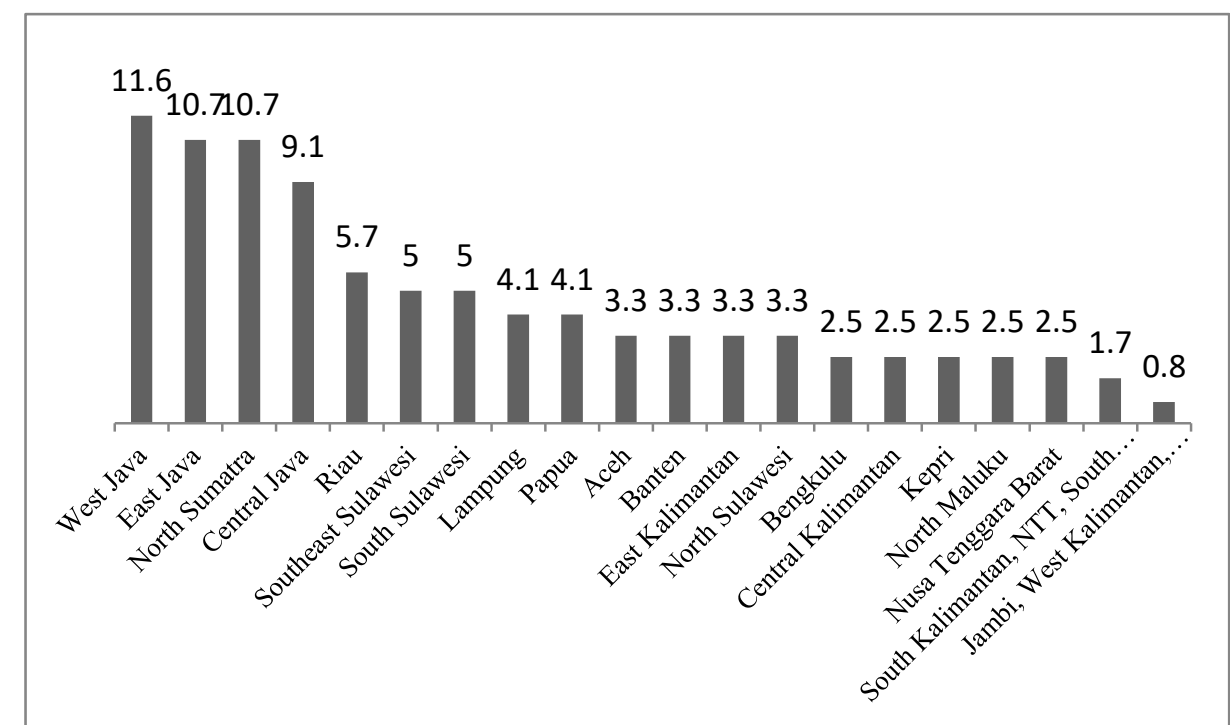

Source: Compass R\&D analysis of 139 corruption cases involving 121 regional heads (Desember, 2019)

Referring to the data above, two things can be concluded. First, corruption is increasingly entrenched in Indonesia which is not only done by the Central Government but also regional heads. Second, the noble goal of decentralization as an effort to democratize the Regional Government to include the people responsible for the administration of government, in fact, it increases corruption in the region. One of the causes is that decentralization and regional autonomy have not been accompanied by accountability. According to Maravic (2007), the existence of decentralization and autonomy has led to reduced supervision and encouraged corruption in the public sector. This is also shown by the results of Wu's study (2005) which shows that decentralization without accountability will have a positive impact on the level of corruption. Due to decentralization increases the discretion of LGs in managing finances, thus increasing the chances of corruption if not accompanied by an adequate control system (Klitgaard (1998) in Dwi, 2017).

In the table above it can also be seen that corruption is spreading evenly throughout Indonesia. Consequently, the CPI released by Transparency International Indonesia (TII) has been stagnant in suspension 37 for two consecutive years (2016 and 2017). Although in 2018 the suspension increased by 1 point to 38 (Transparency International, 2018). For this 
Vol..06, No.01, 2020

Doi: https://doi.org/10.24198/cosmogov.v6i1.23944

http://jurnal.unpad.ac.id/cosmogov/index

reason, eradicating corruption is an important agenda to be realized, considering that corruption has a bad impact on the social fabric of society. Several studies (Mauro, 1995; Mo, 2001; Meon and Sekkat, 2005; Fisman and Miguel, 2008; Yamamura, Andres, and Katsaiti, 2012) found various effects of corruption on the field of community life in the economic, social and cultural fields.

One mechanism to reduce the level of corruption is to reduce the direct relationship between government employees and the community (Klitgaard (1998) in Dwi (2017)). The existence of information and communication technology is an appropriate tool in this strategy (Elbahnasawy (2014) in Dwi (2017). In this context, information technology as an intermediary for interaction between parties so that face-toface meetings in discussing government projects and activities can be minimized. The effect, corruption gap can be suppressed With the use of e-government, the community is a means of controlling governance so that public services are provided more easily, efficiently, effectively, free of corruption and illegal fees.

\section{E-Government Relations \\ Corruption in Indonesia} and

The government's noble intention to eradicate corruption is reflected in the start of implementing e-government by referring to Presidential Instruction No. 3 of 2003 concerning National Policy and Strategy for E-Government Development. The regulation mandates all community organizations to start using information and communication technology (ICT) in public administration. E-Government is the use of information technology by the government to provide information and services for its citizens, business affairs, and other matters relating to government. In principle, egovernment can be utilized to improve efficiency, effectiveness, transparency, and accountability in the administration of government; and improve effective and efficient public services.

However, referring to the 2018 United Nations E-government Survey English EGDI (E-government Development Index) in 2018 ranked 107th, up to 9th rank compared to 2016 which was ranked 116th. Meanwhile, for the ASEAN region, Indonesia was ranked 7th after Vietnam, is still the same as in 2016. Indonesia's ranking is still far below other ASEAN countries such as Singapore (ranked 7), Malaysia (ranked 48), Brunei Darussalam (59), Thailand (73), Philippines (75), and Vietnam (88). The average value of Indonesia's EGDI is also below the average in the Southeast Asian region. Indonesia stands at 0.5258 while the average EGDI in the Southeast Asian region is 0.5555 .

Contrary to the UN survey, the survey conducted by the Ministry of communication and information (Kemenkominfo) showed that most (13 out of 20) of the provinces surveyed had good results in implementing e-government. Meanwhile, 7 provinces get "not good" results. These results should further encourage the government to be able to further enhance the implementation of $\mathrm{E}$ government throughout the country by 
Vol..06, No.01, 2020

Doi: https://doi.org/10.24198/cosmogov.v6i1.23944

http://jurnal.unpad.ac.id/cosmogov/index

increasing competence in the field of ICT

and ICT infrastructure.

Table 3 Survey of e-government implementation in Indonesian Provinces (0-4 scale with 0 indicates low performance and 4 indicates high performance)

\begin{tabular}{|c|c|c|c|c|c|c|c|c|}
\hline \multirow{2}{*}{ No } & \multirow{2}{*}{ Province } & \multicolumn{5}{|c|}{ Dimension } & \multirow[b]{2}{*}{ average point } & \multirow[b]{2}{*}{ category } \\
\hline & & Policies & Institutions & Infrastructure & application & planning & & \\
\hline 1 & DKI Jakarta & 3.50 & 3.40 & 3.37 & 3.57 & 3.13 & 3.39 & Good \\
\hline 2 & West Java & 2.80 & 3.07 & 3.20 & 3.13 & 3.13 & 3.07 & Good \\
\hline 3 & East Jawa & 3.27 & 3.20 & 3.20 & 2.80 & 2.57 & 3.01 & Good \\
\hline 4 & Gorontalo & 2.67 & 2.73 & 2.80 & 3.40 & 3.13 & 2.95 & Good \\
\hline 5 & Bangka Belitung & 2.50 & 3.00 & 3.20 & 2.79 & 3.00 & 2.90 & Good \\
\hline 6 & D.I Yogyakarta & 2.90 & 2.50 & 2.50 & 2.80 & 2.60 & 2.66 & Good \\
\hline 7 & Central Java & 3.00 & 2.20 & 2.67 & 2.80 & 2.53 & 2.64 & Good \\
\hline 8 & Bali & 2.50 & 2.50 & 2.80 & 2.80 & 2.53 & 2.63 & Good \\
\hline 9 & North Sumatera & 2.67 & 2.87 & 2.53 & 2.50 & 2.53 & 2.62 & Good \\
\hline 10 & Jambi & 2.50 & 2.50 & 2.73 & 2.83 & 2.50 & 2.61 & Good \\
\hline 11 & NTB & 2.60 & 2.50 & 2.40 & 2.57 & 2.63 & 2.54 & Good \\
\hline 12 & East Kalimantan & 2.80 & 2.70 & 2.80 & 2.50 & 1.80 & 2.52 & Good \\
\hline 13 & Aceh & 2.33 & 2.33 & 2.53 & 2.53 & 2.80 & 2.51 & Good \\
\hline 14 & South Sumatera & 2.20 & 2.33 & 2.53 & 2.20 & 2.40 & 2.33 & Less good \\
\hline 15 & West Sumatera & 2.07 & 1.93 & 2.13 & 2.13 & 1.80 & 2.01 & Less good \\
\hline 16 & South Kalimantan & 2.00 & 2.00 & 1.53 & 1.93 & 1.93 & 1.88 & Less good \\
\hline 17 & Lampung & 1.93 & 1.53 & 1.73 & 1.87 & 1.73 & 1.76 & Less good \\
\hline 18 & Central Sulawesi & 1.87 & 1.93 & 1.53 & 1.67 & 1.67 & 1.73 & Less good \\
\hline 19 & West Sulawesi & 1.60 & 1.53 & 1.60 & 2.07 & 1.80 & 1.72 & Less good \\
\hline 20 & Bengkulu & 1.56 & 1.75 & & & & & Less good \\
\hline & Overall average & 2.5 & 2.4 & 2.5 & 2.5 & 2.4 & 2.5 & Good \\
\hline
\end{tabular}

Source: Ministry of Communication and Information, 2015

Referring to the data above, it is quite clear that almost all public institutions in Indonesia have implemented egovernment. However, whether egovernment has been implemented then corruption is reduced or not. The data described in the previous chapter shows that there are still many regional heads who are suspected of corruption cases. Corruption is still dominated by the public service sector, the impact of efforts to improve community welfare is slow.

However, several studies have concluded that e-government can reduce corruption which has an impact on improving public services. However, data in the field still shows that corruption is still rife. Grönlund (2011), argues that although many research results show a positive correlation between e-government and the eradication of corruption, its validity cannot yet be believed because the index and variables used are derived from so many choices that can be used.

For this reason, the application of e-government must consider the type of corruption intended to be eradicated. Thus, policymakers need to know three groups of corruption. The first group was formed by small bureaucratic corruption (low-level administrative corruption). The second group consists of self-serving assets that are stripped by state officials. The third group is formed by grand political corruption (Shah and Schacter in Pathak et al., 2009).

Among the three categories of corruption mentioned earlier, we can see that e-government implementation is best used to eradicate small bureaucratic corruption, namely corruption involving small-scale, individual bribery and impacting government on citizens (G2C). By building a system or application that promotes transparency and accountability 
Vol..06, No.01, 2020

Doi: https://doi.org/10.24198/cosmogov.v6i1.23944

http://jurnal.unpad.ac.id/cosmogov/index

like the OPEN system in South Korea, this typical corruption can be greatly reduced. But for other types of corruption, it is difficult to deal only with e-government because they also require institutional reform and political will from the state elite. The level of law enforcement and deterrent punishment is very important to control corrupt behavior.

For example, on e-procurement. Indonesia has begun implementing an electronic procurement system (eprocurement) since April 2007 to promote transparency and eradicate corruption which mostly occurs in the procurement process (Choi, Park, Rho \& Zho, 2016). The service goods procurement sector tends to be prone to corruption because most government agencies; procurement expenditure reaches $70 \%$ of the total annual budget (Sideridis \& Patrikakis in Choi et al., 2016). Moreover, since Perpres 54 of 2010 and followed by the Head of LKPP Regulation No.18 of 2012, it has been recommended to all public organizations to use the e-procurement system in the procurement of their goods or services.

However, e-procurement has not been effective in preventing corruption because of interventions between agencies within the executive branch. Interventions can start from the planning stage, sometimes even at the auction stage, the winner of the tender can be known. If the winner of the tender has been determined from the beginning then it can be ascertained that there are corrupt practices. The existence of vertical and horizontal interventions indicates the problem of eprocurement not only comes from the management officials but also providers.
For example, referring to the March 2019 corruption eradication commission (KPK) press release regarding the alleged bribery of goods and services procurement at PT Krakatau Steel in 2019, WNU together with AMU allegedly accepted bribes to influence the procurement of goods and services at PT Krakatau Steel (Persero ). The project value of goods and services procurement is worth Rp24 billion and Rp2.4 billion, respectively. Two other suspects namely KSU and KET allegedly gave bribes to launch their process of obtaining goods and services procurement projects at PT Krakatau Steel (Persero). The process of procuring goods and services is allegedly arranged so that the KSU and KET companies get the project (KPK, 23 March 2019).

The role of e-government for these types of cases only serves to facilitate a more transparent process. But the use of this system is very dependent on the political will of the state elite. The presence of ICTs can help detect and eliminate corruption, but sometimes it has no effect or creates new opportunities for corruption where ICTs can 'enhance corruption skills' (Heeks in Kim et al., 2009). Corruption "has strong roots in cultural, political and economic conditions" (Wescott in Kim et al., 2009, p: 43).

Another factor that can influence the successful implementation of egovernment is the level of internet penetration in the country. South Korea is a successful country in implementing egovernment. This is supported by ICT infrastructure in Korea wherein 2007, more than $90 \%$ of Koreans were able to have 
Vol..06, No.01, 2020

Doi: https://doi.org/10.24198/cosmogov.v6i1.23944

http://jurnal.unpad.ac.id/cosmogov/index

broadband internet in their homes and cellular users also reached 90\% (Kim et al., 2009). In contrast, the use of e-government in Ethiopia to eradicate corruption appears to be limited because the use of the internet in this country is far less than in South Africa which is $7.3 \%$ (Pathak et al., 2010).

Referring to APJII data, internet usage in Indonesia has only reached 171.17 million from 264.16 million people in Indonesia. This means that only $64.8 \%$ of Indonesia's population has access to e- government. While $35.2 \%$ have not. Of the $64.8 \%$, the largest contribution of internet users is in the Java region which accounts for $55.7 \%$, then Sumatra $(21.6 \%)$, Sulawesi-Maluku-Papua $\quad(10.9 \%)$, Kalimantan (6.6\%) and Bali \& Nusa Tenggara (5.2\%). Meanwhile, the use of the internet is more widely used for lifestyle purposes. $18.9 \%$ of internet users use it for social media purposes. Meanwhile, the use of the internet to access public services is only

$0.4 \%$.

Table 4 Reasons for Using the 2018 Internet Survey

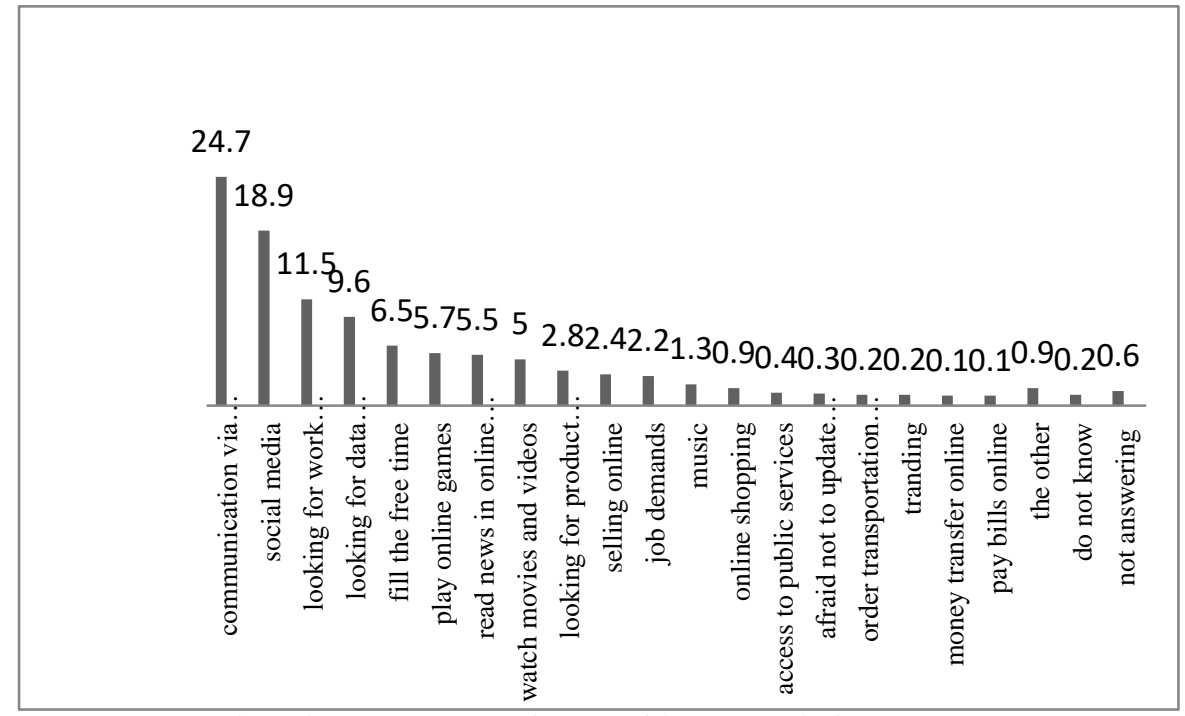

Source: Indonesian Internet Service Providers Association (APJII), 2018.

For this reason, e-government access needs to utilize social media as a form of government communication with the public. The existence of limits on the reach of the internet in rural areas and the still low use of the internet in accessing public information has led to the use of egovernment as an effort to improve the quality of public services aimed at creating good governance and clean governance that has not been running optimally.
For example, e-procurement. As one of the applications of the realization of e-government, e-procurement is considered capable of reducing the potential for corruption in the procurement process of goods / services. Data from the KPK shows that in three years (2017-2019) the number of cases related to goods and services procurement corruption cases was significant, wherein 201715 cases were rising to 17 cases in 2018 and stagnating at 17 in 2019 (KPK, 2019). Not only the 
Vol..06, No.01, 2020

Doi: https://doi.org/10.24198/cosmogov.v6i1.23944

http://jurnal.unpad.ac.id/cosmogov/index

number of cases for 15 years in the case of corruption in the procurement of goods and services but also ranks second (205 cases) after bribery (661 cases). This shows that the implementation of e-procurement has not become a guarantee for agencies free from corruption. The logical consequence is that the procurement of goods and services that were intended to improve public services is not optimal.

\section{CONCLUSION}

Based on the data that has been presented before, it can be concluded that although most institutions have used egovernment, corruption still occurs therein. That is, the application of e-government has not been able to completely prevent corruption. This is based on the possibility that corruption can occur during planning or when the budgeting process starts. For example, when there are public facilities

\section{REFERENCE}

Andersen, B.T. (2009). E-government As An Anti-Corruption Strategy. Information Economics and Policy, 21, 201-210.

Berkovich, I. (2016). The Corrupted Industry and the "Wagon-Wheel Effect": A Cross-Country Exploration of the Effect of Government Corruption on Public Service Effectiveness. Administration and Society, 48 (5), 559-579.

Bertrand, M., Djankov, S., Hanna, R., \& Mullainathan, S. (2007). Obtaining a Driver's Licence in India : An Experimental Approach to Studying Corruption. The Quarterly Journal of Economics, 1639-1676.

Choi, H., Park, M.J., Rho, J.J, Zo, H. (2016). Rethinking the assessment of e-government implementation in such as airports, roads, sports buildings or hospitals being planned, it is no secret that land brokers are speculating to play the price and flirt with planners in the center or the regions.

Thus the potential for comuption carried out more evenly spread to all regions in Indonesia. This can be seen from the data on the number of regional heads caught in corruption cases. And most of the corruption cases committed are related to public services. The greater the public service budget that is corrupted, the more reducing the quality of public services provided and ultimately the community losers. Therefore, the government must diagnose what is lacking in the implementation of e-government. So that a clean and transparent government is realized, the gap for corruption can be closed and good public services achieved.

developing countries from the perspective of the design-reality gap: Applications in the Indonesian e-procurement system. Telecommunications Policy, 40, 644-660.

Davis, J. (2004). Corruption in Public Service Delivery: Experience from South Asia's Water and Sanitation Sector. World Development. 32 (1), 53-71.

Elbahnasawy, N. G. 2014. E-government, Internet Adoption and Corruption: An Empirical Investigation. World Development. 57: 114-126.

Grönlund, A., Flygare, A-M. (2011). The Effect of eGovernment on Corruption: Measuring Robustnessof Indexes . Electronic Government and the Information Systems Perspective . Lecture Notes in Computer Science , 2011, Volume 6866/2011, 235-248, 
Vol..06, No.01, 2020

Doi: https://doi.org/10.24198/cosmogov.v6i1.23944

http://jurnal.unpad.ac.id/cosmogov/index

DOI: 10.1007/978-3-642-229619_19. Available at: http://www.springerlink.com/conte nt/f645xk150k715725/ Internet Adoption and Corruption: An Empirical Investigation. World Development 57: 114-126.

Kim, S., Kim, J.H., \& Lee, H. (2008). An institutional analysis of an $e-$ government system for anticorruption: The case of OPEN. Government Information Quarterly. 26. 42-50.

Klitgaard, R. 1998. International Cooperation Against Corruption. Finance and Development 35(1): 3-6.

Kurniawan, T., Prasojo, E., \& Gunadi (2017). Corruptive Behavior of the Heads of Local Governments in Indonesia. Administrative Culture, $18(1), 73-87$.

Lewis, B. (2017). Local government spending and service delivery in Indonesia: the perverse effects of substantial fiscal resources, Regional Studies, 51 (11), 16951707.

Lubis M dan James CS (Eds) (1985) Bunga Rampai Korupsi. Jakarta: LP3ES.

Maravic, P. V. (2007). Public Management Reform and Corruption Conceptualizing the Unintended Consequences. Administratie Si Management Public 8:126-143.

Fisman, Raymond \&Miguel, Edward. (2008). Economic Gangsters: corruption, violence, and the poverty of nations.Princeton University Press, New Jersey.

Mauro, P. (1995). "Corruption and Growth",The Quarterly Journal of Economics 110(3): 681-712.

Meon, P-G. \&Sekkat, K. (2005). "Does Corruption Grease or Sand the Wheels of Growth?",Public Choice122(1/2): 69-97.

Mo, P.H. (2001). "Corruption and Economic Growth" ,Journal of Comparative Economics 29: 66-79

Nurdin. (2012). Benchmarking Indonesian Local e-Government. PACIS
Conference in Ho Chi Minh Vietnam, paper 61

Olken, B.A. (2007). Monitoring Corruption: Evidence from a Field Experiment in Indonesia. Journal of Political Economy, 115, (2) 200249.

Pathak, R.D., Naz, R., Rahman, M.H., Smith, F.I., \& Agarwal, K.N. (2009). E-Governance to Cut Corruption in Public Service Delivery: A Case Study of Fiji. Intl Journal of Public Administration, $32 \quad$ (5), 415-437, DOI: 10.1080/01900690902799482

Reinnika, R., \& Svensson, J. (2005). Fighting Corruption to Improve Schooling: Evidence from a Newspaper Campaign in Uganda. Journal of the European Economic Association. 3 (2-3), 259-267.

Singh, G., Pathak, R.D., Naz, R., Belwal R. (2010). Fighting Corruption to Improve Schooling: Evidence from a Newspaper Campaign in Uganda. International Journal of Public Sector Management, 3 (6), 254-275.

https://doi.org/10.1108/095135510 11032473

Wong, W. \& Welch, E., (2000). Does Egovernment Promote Accountability? A Comparative Analysis of Website Openness and Government Accountability. International Journal of Policy, Administration, and Institutions, 17 (2), 275-297.

Yamamura, E., Andres. R\&Katsaiti, M. S. (2012). "Does Corruption Affect Suicide? Econometric Evidence from OECD Countries", Atl Econ J40: 133-145.

Compass R\&D analysis of 139 corruption cases involving 121 regional heads (09 Desember, 2019)

Indonesian Internet Service Providers Association, Penetration and Profile of Indonesian Internet Users in 2018 Survey. Accessed 04 Desember 2019. From https://www.apjii.or.id/survei

Corruption Eradication Commission. KPK Sets Four Suspects in the Case of 
Vol..06, No.01, 2020

Doi: https://doi.org/10.24198/cosmogov.v6i1.23944

http://jurnal.unpad.ac.id/cosmogov/index

Bribery in the Procurement of Goods and Services at PT Krakatau Steel. Accessed 04 Desember 2019. From https://www.kpk.go.id/id/berita/siar an-pers/809-kpk-tetapkan-empattersangka-dalam-kasus-suappengadaan-barang-dan-jasa-di-ptkrakatau-steelKompas. Orang Indonesia Pakai Internet untuk Apa?. Accessed 04 Desember 2019.

From

https://tekno.kompas.com/read/201 8/02/22/20080077/orangindonesia-pakai-internet-untukapa-?page $=$ all

Rahma, Sakina. In 2017, Internet Users in Indonesia Reached 143.26 Million People. Accessed 04 Desember 2019.

From https://ekonomi.kompas.com/read/ 2018/02/19/161115126/tahun2017-pengguna-internet-diindonesia-mencapai-14326-jutaorang.

National Secretariat of the Indonesian Forum for Budget Transparency. Corruption (already) Occurred Since Budget Planning. Accessed 04 Desember 2019. From https://seknasfitra.org/korupsisudah-terjadi-sejak-perencanaananggaran/

Tirto, Dismantling Corruption of Infrastructure Projects. Accessed 02 April 2020. From https://tirto.id/membongkarkorupsi-proyek-infrastruktur-cfke
Transparency International. Corruption Perception Index 2018. Accessed 04 Desember 2019. From https://www.transparency.org/cpi2 $\underline{018}$

United Nations. United Nations Egovernment Survey 2018. Accessed 02 Desember 2019. From https://publicadministration.un.org/ en/Research/UN-e-governmentSurveys

Ombudsman, Internalization of public service standards. Accessed 02 Desember 2019. From https://ombudsman.go.id/artikel/r/a rtikel--internalisasi-standarpelayanan-publik

Ombudsman. Projected improvement in the quality of public services. Accessed 02 April 2020. From https://ombudsman.go.id/artikel/r/a rtikel--proyeksi-peningkatankualitas-pelayanan-publik-2020

United Nations. United Nations Egovernment Survey. Accessed 02 Desember $2019 . \quad$ From https://publicadministration.un.org/ egovkb/en-us/Data/RegionInformation/id/17Asia\%E2\%80\%94South-easternAsia

Ministry of ICT Republic of Indonesia. PeGI Ranking 2015. Accessed 02 Desember 2019. From http://pegi.layanan.go.id/tabelhasil-pegi-4/ 